\title{
Local Tissue Damage in Cows after Intramuscular Injections of Eight Antimicrobial Agents
}

\begin{abstract}
Antimicrobial agents are usually administered to cattle intramuscularly (im). After im injections, tissue damage at the injection sites may occur. This may be caused by the vehicle, the active ingredient, or both. Other factors affecting tissue reaction are $\mathrm{pH}$, osmotic status, injection volume, concentration of the antimicrobial agent, and the injection technique used. Repeated injections and large injection volumes promote tissue damage (Kern 1987).
\end{abstract}

Several methods have been used to measure tissue reactions after drug injections. The histopathological method, where the size and type of the necrotic area are investigated after slaughter of the animal (Rasmussen \& Svendsen 1976), has perhaps been the most frequently used. A further possibility is to monitor muscle damage by measuring the activity of muscle specific enzymes including serum creatine phosphokinase (CK) (Diness 1985, Kern 1987). The use of serum CK provides an organ-specific method indicating muscle damage (Braun et al. 1992). Intramuscular injections increase CK activity owing to local areas of muscle necrosis (Steiness et al. 1978).

Ultrasound scanning of the injection site, to indicate tissue damage, has also been suggested (Banting 1991). Clinical pain reactions of the animals should be monitored along with biochemical or other methods.

The aim of the present study was to compare tissue reactions caused by different commonly used antimicrobial injectables in cows. The antimicrobial preparations investigated and the dosages used are listed in Table 1. Dosage of the preparations was based on current recommendations for therapy of lactating cows (van Miert et al. 1988, Pharmaca Fennica Veterinaria 1992-93). Thirteen clinically healthy 2-6 year old Ayrshire cows and heifers were used as experimental animals. The animals weighed on average $330-540 \mathrm{~kg}$. Each preparation was administered to 4 animals. When the same animals were used, there was an interval of at least 1 month between injections of different drugs. Antimicrobials were administered as 2 deep intramuscular injections into both sides of the neck (M. trapezius, $M$. serratus cervicis ventralis), using an $18 \mathrm{G}$ disposable needle. The total injection volumes of the drugs ranged between 32 and $53 \mathrm{ml}$ (for Baytril ${ }^{\circledR}$ between 21 and $24 \mathrm{ml}$ ). Physiological saline $(2 \times 20-25 \mathrm{ml} \mathrm{NaCl})$ was used as a control.

Injection sites were inspected and palpated during the experimental period by the same person, who was unaware of the treatment details. Clinical reactions such as swelling or pain at the injection sites were recorded. Blood samples for CK-analysis were drawn from the jugular vein via a permanent cannula before injection and $2,4,8,12,24,32$, and 48 $\mathrm{h}$ after injection. The blood was allowed to clot for $4 \mathrm{~h}$ at room temperature and the serum was separated and frozen until analysis. 
Table 1. The dose and the mean area under the curve (AUC mean \pm s.d., $0-48 \mathrm{~h}$ ) of serum creatıne phosphokınase actıvity for 8 antımicrobial preparations (actıve ingredıent in parentheses).

\begin{tabular}{|c|c|c|c|}
\hline $\begin{array}{l}\text { Preparation } \\
\text { (Active ingredient) }\end{array}$ & $\begin{array}{l}\text { Dose } \\
(\mathrm{mg} / \mathrm{kg})\end{array}$ & $\begin{array}{l}\text { Injection } \\
\text { vol (ml)* }\end{array}$ & $\underset{(\mathrm{U} / \mathrm{A} \pm \mathrm{s})}{\mathrm{AUC}}$ \\
\hline $\begin{array}{l}\text { Baytril }{ }^{\circledR} \text {, Bayer AG, Germany } \\
\text { (enrofloxacin) }\end{array}$ & 5 & 21.9 & $75000 \pm 24000$ \\
\hline $\begin{array}{l}\text { Borgal }^{\circledR}, \text { Hoechst, Germany } \\
\text { (trimethoprim-sulphadoxine) }\end{array}$ & 24 & 45.5 & $34000 \pm 17000$ \\
\hline $\begin{array}{l}\text { Engemycin }{ }^{\circledR} \text {, Gist-Brokades Anım. } \\
\text { Health, UK (oxytetracycline) }\end{array}$ & 10 & 43.0 & $19500 \pm 5200$ \\
\hline $\begin{array}{l}\text { Ethacilin }{ }^{\circledR} \text {, Intervet Int. B.V. } \\
\text { Holland (penicillın G procaine) }\end{array}$ & 20 & 37.5 & $5.600 \pm 1200$ \\
\hline $\begin{array}{l}\text { Spiramycin }^{\circledR}, \text { Pherrovet AB, } \\
\text { Sweden (spiramycın) }\end{array}$ & 10 & 49.0 & $14000 \pm 4500$ \\
\hline $\begin{array}{l}\text { Terramycin LA }{ }^{\circledR}, \text { Pfizer Inc., } \\
\text { U.S.A. (oxytetracycline) }\end{array}$ & 20 & 46.2 & $19000 \pm 10000$ \\
\hline $\begin{array}{l}\text { Tribrissen }{ }^{\circledR} \text {, Pitman-Moore LTD., } \\
\text { U.K. (trimethoprım-sulphadiazine) }\end{array}$ & 48 & 50.2 & $14900 \pm 5900$ \\
\hline $\begin{array}{l}\text { Tylan }^{\circledR}{ }^{\circledR} \text { Elanco, Lilly Indust. } \\
\text { LTD., U.K. (tylosine) }\end{array}$ & 10 & 35.4 & $37000 \pm 18000$ \\
\hline $\mathrm{NaCl}$ (control) & & 475 & $5500 \pm \quad 430$ \\
\hline
\end{tabular}

* Mean total injection volume (ml) of the drug, divided into 2 parts when injected.

CK activity was assessed by routine methods (Anon. 1976). Values were compared with basal levels recorded before drug administration.

Most preparations provoked a marked rise in serum CK activity. Geometric means of CK activities for the preparations during $48 \mathrm{~h}$ are shown in Fig. 1. Mean area under curve (AUC) values for different drugs calculated from the serum CK concentration-time curves $(0-48 \mathrm{~h})$ are given in Table 1 . The basal CK level before drug injections ranged between 76 and $199 \mathrm{U} / 1$ (the reference value for adult cows is $50-220 \mathrm{U} / 1)$.

The preparation containing enrofloxacin $\left(\right.$ Baytril $\left.^{\circledR}\right)$ induced the highest serum CK response. Baytrill ${ }^{\circledR}$ increased the serum CK activity by up to 16 times that before drug administration.

Tylosin $\left(\operatorname{Tylan}^{\circledR}\right)$ and the combination trimethoprim-sulphadoxine $\left(\right.$ Borgal $\left.^{\circledR}\right)$ also caused marked irritation, seen as high postinjection CK levels. Ethacilin ${ }^{\circledR}$, containing penicillin $G$, was the only preparation in this study that did not significantly elevate CK activity beyond the basal level. It was comparable with the $\mathrm{NaCl}$ control. This agrees with earlier reports in which only a very mild reaction was observed with im injections of penicillin G procaine (Luthman \& Jacobsson 1989).

Clinical reactions - pain, swelling or both at the injection sites - were noted in many of the animals. The most serious clinical reactions were found after injections of Borgal ${ }^{\circledR}$, Spiramycin ${ }^{\circledR}$, and Terramycin LA ${ }^{\circledR}$ : clearly swollen and painful injection sites were recorded in 3 animals out of 4 . Baytril ${ }^{\circledR}$, which increased serum CK most, produced small swellings in 3 animals but no signs of pain. The rest of the drugs induced mild clinical reactions in 1 or 2 of the 4 animals. $\mathrm{NaCl}$ stimu- 
Figure 1. Time-concentration curves of serum creatine phosphokinase (CK) after intramuscular injections of 8 antimicrobials (geometric means of 4 cows).

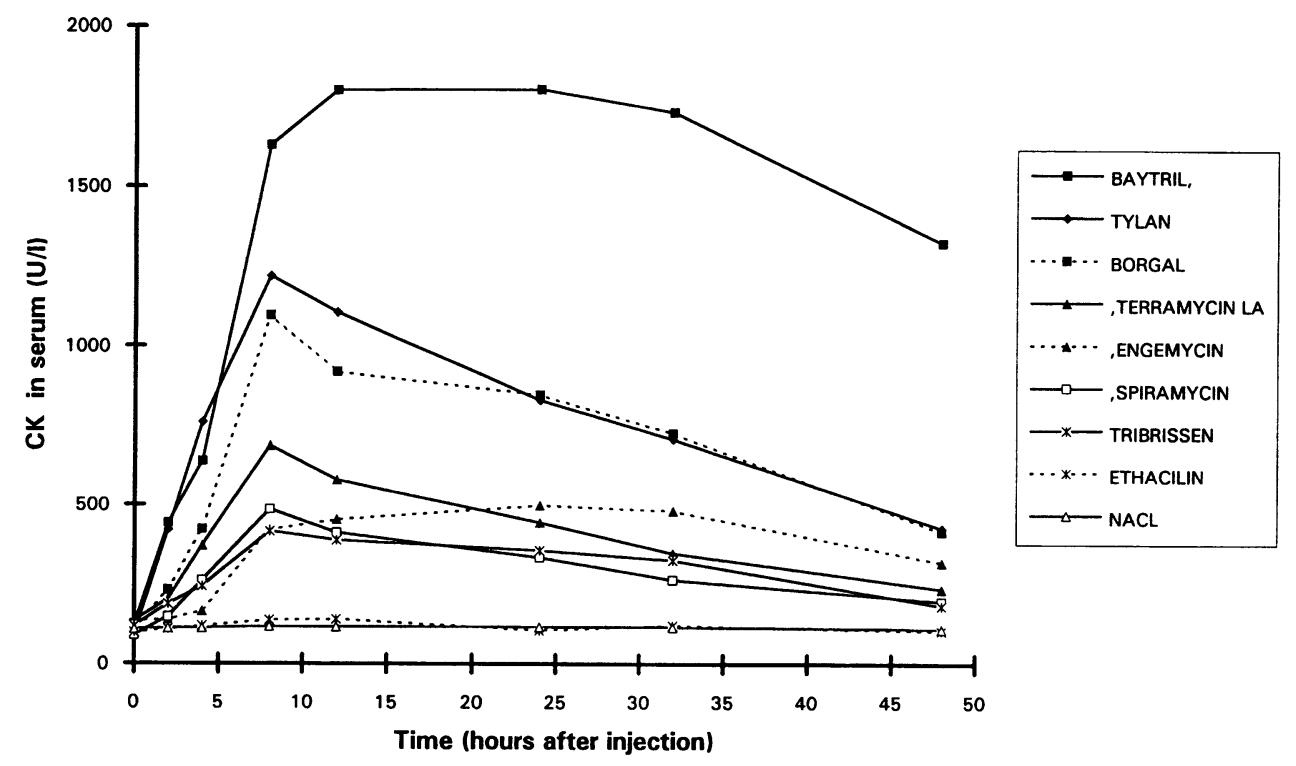

lated a short-lived mild clinical reaction in 1 animal only. Thus, a certain trend could be seen but still clinical findings did not completely agree with results from CK measurements. Clinical methods are inaccurate and subjective for examining tissue reactions after injections. It has also been shown that a deep im injection can cause serious tissue damage without visible signs of pain (Luthman \& Jacobsson 1989).

Oxytetracycline and macrolides are known to provoke substantial tissue damage (Rasmussen \& Hogh 1971, Häninchen et al. 1984, Nouws et al. 1990). In the present study, both oxytetracycline preparations (Engemycin ${ }^{\circledR}$, Terramycin LA ${ }^{\circledR}$ ) and spiramycin (Spiramy$\left.\operatorname{cin}^{\circledR}\right)$ were very similar to each other in causing a moderate reaction. Contrary to the results of previous studies (Xia et al. 1983, Nouws et al. 1990), no differences were found between the 2 oxytetracycline preparations.
Since the studies of Nouws et al. (1990), the formulas have been altered and thus the results cannot be compared. In the study by Xia et al. (1983), $10 \%$ and $20 \%$ oxytetracycline injectables (manufacturer not mentioned) were compared. The concentrated preparation was found to be more tissue damaging and cause prolonged residues at the injection site.

Among vehicles used for the preparations examined here at least glycerol formal (Bor$\mathrm{gal}^{\circledR}$ ) and propylene glycol $\left(\right.$ Tylan $^{\circledR}$ ) have been shown to be tissue irritants (Rasmussen \& Svendsen 1976). These preparations induced the highest CK response in this study. Apparently, both the active ingredient and vehicle contribute to the severe effect of Tylan ${ }^{\circledR}$. Tissue irritation is an undesirable side-effect of a drug. Manufacturers should warn veterinarians about possible side-effects of their products in the summary of product characteristics. Tissue damage after im injections of 
different drugs should be monitored in parallel with pharmacokinetic studies. For reasons of animal welfare, irritation is not acceptable, but it also has negative effects from the pharmacokinetic and food hygiene point of view.

\section{Acknowledgements}

The authors thank Satu Sankari, DVM, PhD, Central Laboratory of the College of Veterinary Medicine, for analysis of CK.

S, Pyorala, L. Manner, E. Kestl, and M. Sandholm, Department of Clinical Sciences, College of Veter1nary Medicine, SF-04840 Hautjärvi and SF-00581 Helsınkı, Finland.

\section{References}

Anonymous: The Committee on Enzymes of the Scandınavian Society for Clinical Chemistry and Clinical Physiology: Recommended method for the determination of creatine kinase in blood Scand. J. Clin. Lab. Invest. 1976, 36, 711-723.

Banting A, Tranquart F: Echography as a tool in clinical pharmacology. Acta vet. scand. 1991, Suppl. 87, 215-216.

Barun JP, Lefebre H, Aktas M, Rico AG, Toutain $P L$ : Biochemical markers of skeletal muscle damage in comparative biology. 5th Congress of ISACB, Parma, 1992, 53-59.

Diness $V$. Local tissue damage after intramuscular injections in rabbits and pigs: Quantitation by determination of creatıne kiase actıvity at injection sites. Acta Pharmacol. toxicol. 1985, 56, 410-415.

Haninchen T, Geyer K, Dirksen G. Untersuchungen uber Gewebereizungen und -nekrosen nach intramuskularer Injektion von antibakteriellen
Praparaten bei Kalb und Kanınchen (Investigation on tissue irritation and necrosis in calves and rabbits following intramuscular injection of ant1bacterial drugs). Tierarztl. Umschau 1984, 39, 75-80.

Kern, $O$ : Lokalvertraglichkeit von Arzne1- und Arzneihilfstoffen bei intramuskularer Injektion (Local effects of intramiscular drug injections). Teil 1-3. Tierärztl. Umschau 1987, 42, 768-775, 912-916, 971-972.

Luthman J, Jacobsson SO: Vavnadsirriterande lakemedel (Tissue irritating drugs). Svensk Vet. Tidn. 1989, 41, 433-437.

Nouws JF, Smulders A, Rappalını M. A comparative study on irritation and residue aspects of five oxytetracycline formulations administered intramuscularly to calves, pigs and sheep. Vet. Quart. 1990, 12, 129-138.

Rasmussen $F$, Svendsen $O$ : Tissue damage and concentration at the injection site after intramuscular injection of chemotherapeutics and vehicles in pigs. Res. Vet. Sc1 1976, 20, 55-60.

Rasmussen $F$, Hogh P. Lokalirritation og koncentratıoner på injektionsstedet efter intramuskulær injektion af antıbıtikaholdıge præparater på køer og grise (Irritatıng effect and concentrations at the injection site after intramuscular injection of antibiotic preparations in cows and pigs). Nord. Vet.-Med. 1971, 23, 593-605.

Steiness E, Rasmussen F, Svendsen O, Nielsen P: A comparatıve study of serum creatine phosphok1nase (CPK) activity in rabbits, pigs and humans after intramusculaar injection of local damaging drugs. Acta pharmacol. 1978, 42, 357-364.

van Miert ASJPAM, van Meer RAJM, Hogerhuss $F$, Vos $M$ - Veterinary Antimicrobial Therapy Guide. Alfasan Nederland Bv, Utrecht, The Netherlands 1988, 16-17.

Xıa W, Gyrd-Hansen N, Nielsen P: Comparison of pharmacokınetic parameters for two ocytetracycline preparations in pigs. J. vet. Pharmacol. Therap. 1983, 6, 113-120.

(Recelved August 18, 1993; accepted November 5, 1993).

Reprints may be requested from: S. Pyorala, Department of Clinıcal Sciences, College of Veterinary Medicine, SF-04840 Hautjarvi, Finland. 